2014

\title{
USING MOSSES TO ASSESS CONDITIONS IN NORTHERN WHITE CEDAR SWAMPS
}

Vaula L. M. Lukkarinen

Michigan Technological University

Follow this and additional works at: https://digitalcommons.mtu.edu/etds

Part of the Forest Sciences Commons

Copyright 2014 Vaula L. M. Lukkarinen

\section{Recommended Citation}

Lukkarinen, Vaula L. M., "USING MOSSES TO ASSESS CONDITIONS IN NORTHERN WHITE CEDAR

SWAMPS", Master's Thesis, Michigan Technological University, 2014.

https://doi.org/10.37099/mtu.dc.etds/877

Follow this and additional works at: https://digitalcommons.mtu.edu/etds

8 Part of the Forest Sciences Commons 


\title{
USING MOSSES TO ASSESS CONDITIONS IN NORTHERN WHITE CEDAR SWAMPS
}

\author{
By
}

Vaula L. M. Lukkarinen

\begin{abstract}
A THESIS
Submitted in partial fulfillment of the requirements for the degree of MASTER OF SCIENCE

In Forest Ecology and Management
\end{abstract}

MICHIGAN TECHNOLOGICAL UNIVERSITY

2014

(C) 2014 Vaula L. M. Lukkarinen 
This thesis has been approved in partial fulfillment of the requirements for the Degree of MASTER OF SCIENCE in Forest Ecology and Management.

School of Forest Resources and Environmental Science

$\begin{array}{ll}\text { Thesis Co-Advisor: } & \text { Rodney A. Chimner } \\ \text { Thesis Co-Advisor: } & \text { Harri Vasander } \\ \text { Committee Member: } & \text { Christopher R. Webster }\end{array}$

Committee Member: Alex S. Mayer

School Dean: Terry Sharik 


\section{Table of contents}

ACKNOWLEDGEMENTS ....................................................................................

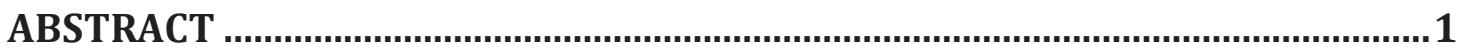

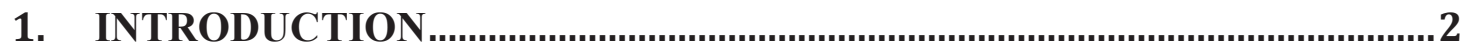

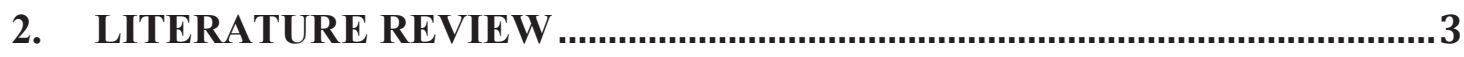

2.1 Northern white cedar and northern white cedar swamps.....................................................

2.2 Mosses and disturbance - how mosses are affected by disturbance .................................... 6

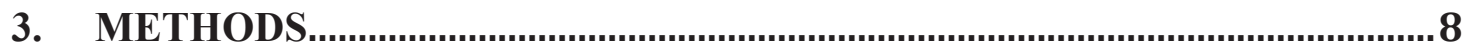

3.1 Study sites

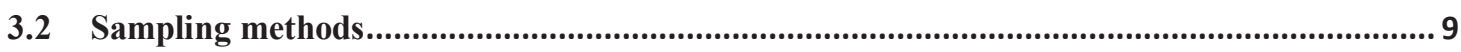

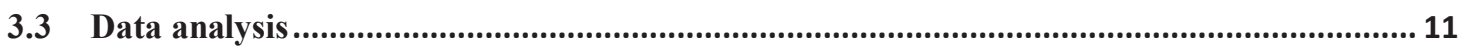

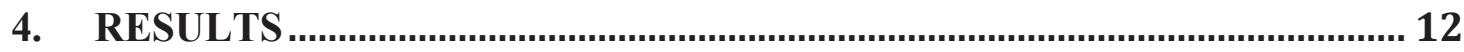

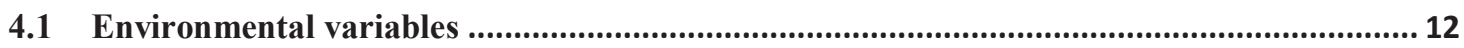

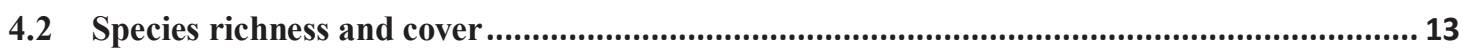

4.3 Moss community composition ........................................................................................... 16

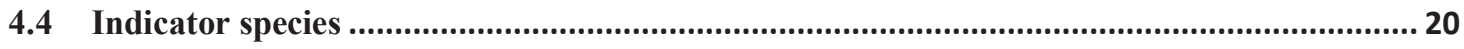

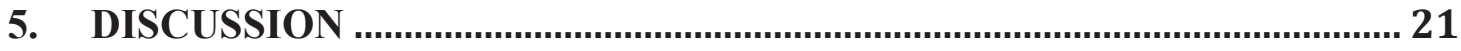

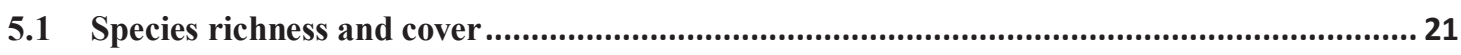

5.2 Moss community composition .......................................................................................... 22

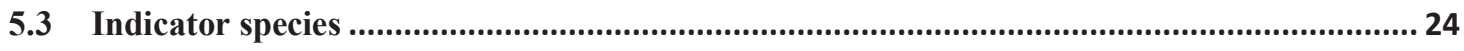




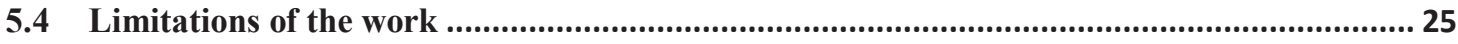

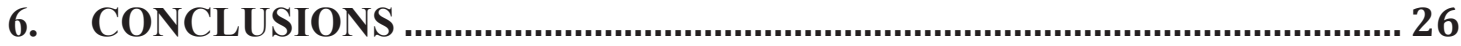

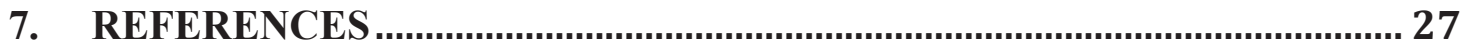

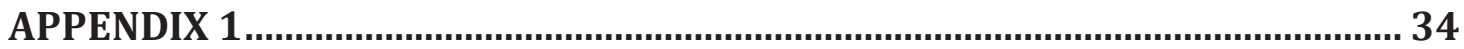

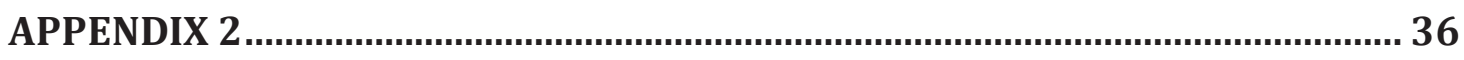




\section{Acknowledgements}

I am deeply grateful to my advisors Rodney Chimner, from Michigan Technological University, and Harri Vasander, from University of Helsinki, for their guidance and valuable input on the thesis, and help with editing. My thanks also go out to the rest of my committee, Chris Webster and Alex Mayer, for their final input. My work was funded by McIntire. I am grateful to everybody involved in the Atlantis program for making this opportunity possible. I would also like to thank Jace Fritzler and Cassandra Ott for their help and company in the field and John Hribljan for borrowing his moss books. Finally, I want to express my gratitude to my friends and family for their support, positivity and understanding when I was busy with my studies. 


\section{Abstract}

Northern white cedar (Thuja occidentalis L.) (NWC) swamps are valuable both commercially and ecologically. Unfortunately, many NWC swamps are degraded and information about them is not abundant. Especially there have been no definitive studies about mosses in northern white cedar swamps and how they react to disturbances. Mosses are sensitive to changes in their environment and thus they could be used to assess ecosystem conditions of NWC swamps.

The objective of this study was to determine if mosses could be used to asses conditions in NWC swamps and if there are differences between moss communities in disturbed and undisturbed sites. Seventeen sample plots were taken from 12 disturbed and undisturbed sites around upper Michigan and northern Minnesota in the summer of 2012. All mosses occurring on the plots were identified and several associated environmental parameters were measured.

The main environmental conditions affecting moss communities were identified with non-metric multidimensional scaling (NMS). Multiple response permutation procedures (MRPP) were run to ascertain if there were significant differences in community composition between disturbances. Indicator species analysis was then done to identify species that are related to different types of disturbances. A one-way ANOVA was used to check for significant differences between species richness and moss cover of undisturbed and disturbed sites.

Over all sixty-two moss species were identified. The results indicate that there was no significant difference in species richness or moss cover between disturbed and undisturbed sites. However, moss community composition was affected by disturbance and strongly divided by a wetness gradient. Dicranum fuscescens was found to indicate undisturbed conditions. Calliergon cordifolium and Climacium dendroides indicated disturbed sites with wet conditions. Brotherella recurvans and Eurhynchium pulchellum indicated swamps with other disturbances. 


\section{Introduction}

Northern white cedar (NWC) (Thuja occidentalis L.) occurs around the Great Lakes and to the east in USA and Canada (Johnston 1990). NWC swamps are important ecosystems for wildlife habitat, with ecosystem services including carbon storage, and they have commercial and cultural value (The feasibility of... 2000). However, many NWC swamps are currently degraded and are considered to be in a vulnerable state (Kost et al. 2007).

Despite the importance of NWC swamps, there is very little information on either cedar trees or NWC swamp ecosystems. NWC swamps are known to be one of

the most biodiversity rich ecosystems in the Great Lakes Region, especially because of the high number of bryophytes (Kost et al. 2007). However, there is actually little information about bryophyte abundance in NWC swamps. Most studies that do mention mosses, only mention the sites having Sphagnum and other mosses in general with little species level identification. Some of these other mosses that have been found in NWC swamps are Mniums, Hylocomium splendens and Dicranum undulatum (Curtis 1946). Holcombe (1967) identified bryophyte flora on logs in NWC swamps and found an average of 6.5 moss species on a log in the middle stage of decay. The logs were dominated by mat forming species, with highest occurrences for Heterophyllium haldanianum and Pleurozium schreberi.

Mosses usually have narrow habitat ranges and are sensitive to changes in their environment (Mälson et al. 2007, Vitt and Wieder 2009, Kangas et al. 2014). Due to this sensitivity, they can make ideal indicators for environmental change (Vellak 2000, Vitt and Wieder 2009). Species that can be used to asses certain environmental conditions, like levels of pollution, are called indicator species. Inventorying presence/absence is a common way of using indicator species (Landres et al. 1988). Having an easily viewed indicator, such as specific moss species or moss cover percentage, could help with assessing conditions of NWC swamps or determining degrees of success in restoration. Some mosses are more sensitive than others, and 
sensitive to different environmental parameters (Bates 2009), so it remains to be seen which species would act best as indicators in NWC swamps.

The goals of this research were to determine if mosses can be used to assess conditions in NWC swamps and if there are certain species that can be used as indicators. I also set out to determine the moss species of NWC swamps. I hypothesize that moss cover, species richness and community structure will change in NWC swamps as a result of disturbance type and severity.

\section{Literature review}

\subsection{Northern white cedar and northern white cedar swamps}

Northern white cedar (NWC) belongs to the cypress family. NWC is a medium sized tree that typically reaches $14 \mathrm{~m}$ in height with a diameter of 30 to $60 \mathrm{~cm}$; however it is long lived and can live over 1000 years in uplands, and over 400 years in swamps (Johnston 1990). NWC is an important tree species commercially, culturally, and for habitat. To the Native Americans, cedar is a sacred plant and most parts of it are utilized. It is thought to purify the body and to help ward off evil (The feasibility of... 2000). There is also evidence that the alcohol extract of NWC could be helpful for radiotherapy patients to reduce the effects of gamma radiation (Sunila and Kuttan 2005).

As building material, NWC wood is strong, light weight, elastic and rot resistant and is predominately used for roof shingles and fence posts (Johnston 1990, The feasibility of... 2000, Boulfroy et al. 2012). Overall, NWC swamps have a high biodiversity with more than 100 plant species found in NWC swamps (The feasibility of... 2000, Kost et al. 2007). NWC swamps also provide valuable habitat and browse for animals, especially white-tailed deer (Odocoileus virginianus) that use cedar as winter cover and food (Aldous 1941). Indigenous bird species also use NWC swamps 
as breeding areas and many rare plant and animal species occur there. For example cranberry (Vaccinium vitis-idaea) is a state endangered plant that can be found in NWC swamps (Kost et al. 2007).

The range of NWC is restricted to North America. It spans from north-eastern Minnesota, through the middle of the Lower Peninsula of Michigan, east to the coast and north to southern east Canada. NWC also occurs spottily outside of its main range as far south as western North Carolina and eastern Tennessee in the mountains, and north in northwest Ontario (Johnston 1990). Cedar grows both on peatlands and mineral soil, especially in calcareous areas (Johnston 1990).

NWC swamps are characterized by woody peat and mineral rich ground water (Johnston 1990, Kost et al. 2007). NWC prefers a pH between 6 and 8 (Curtis 1946, Nelson 1951). The other tree species that commonly co-occur with NWC in swamps are balsam fir (Abies balsamea) and tamarack (Larix laricina) (Johnston 1990). Microtopography, defined as small variations in elevation of surface, consisting of hummocks/mounds, pools/pits and flat mucky areas, is common in NWC swamps (Chimner and Hart 1996, Kost et al. 2007). In relatively non-dense stands there is often an understory of shrubs and herbs and the ground is covered in mosses and liverworts (Eyre 1980 in Johnston 1990). Wind throws are naturally common in NWC swamps and can be a dominant form of reproduction as the lateral branches of a windblown tree can form into main stems (Johnston 1990). Layering and other forms of vegetative regeneration can also be important to NWC but they are often hampered by browsing, unless the branches have already grown above the browse line (Nelson 1951, Pregitzer 1990). In Minnesota swamps, NWC has been found to have regenerated largely by layering in canopy gaps (Zenner and Almendinger 2012).

The majority of commercial cedar stands occur in swamps, where they are relatively safe from fire and have a competitive edge on other species (Eyre 1980 in Johnston 1990). However, throughout its range, NWC stands that have been harvested often fail to regenerate (Heitzman et al. 1997, Heitzman et al. 1999, Boucher et al. 2006, Larouche et al. 2010). In addition, many cedar stands in upland forests were 
previously harvested and discouraged from regenerating. For example, in Minnesota there has been a 45\% (250,000 ha) decline in NWC forest area since the early $1900 \mathrm{~s}$ due mostly to changes in land use or species shifts in forests (Zenner and Almendinger 2012).

The failure of regeneration is usually due to insufficient recruitment into the sapling stage and greater size classes (Heitzman et al. 1997, Rooney et al. 2002). This can be a problem in both harvested and unharvested forests. As a result many harvested cedar stands have been replaced by other tree species, mainly hardwoods and balsam fir (Zasada 1952, Zenner and Almendinger 2012). Seedling establishment of cedar is typically not the limiting factor, but deer often eat almost all seedlings before they grow big enough to escape browsing (Rooney et al. 2002). Browsing by animals, especially deer, is considered one of the main reasons for this recruitment failure (Verme and Johnston 1986, Heitzman et al. 1997, Kost et al. 2007, Larouche et al. 2010). NWC is a preferred browse species for deer, and deer populations have grown dramatically. As a result of heavy browsing, few seedlings grow above $30 \mathrm{~cm}$. It can take many decades for a seedling to reach a height where it is safe from browsing (Rooney and Waller 2003, Hofmeyer et al. 2009, Larouche et al. 2010).

Most NWC seedlings germinate on decaying wood in the middle states of decay with a high moss cover ( 90\%) (Holcombe 1976, Rooney et al. 2002). However, long term survival of cedar in swamps has been found to be better on hummocks (Rooney et al. 2002). The soil in hummocks is not as water logged as on flat ground, which makes germination and survival more probable (Chimner and Hart 1996). It seems that about $70 \%$ or more hummock area in the swamp is needed for cedar to be the dominating tree species. With a smaller percentage of hummock area, shrubs and hardwood species adapted to wetter conditions could become the dominating species (Chimner and Hart 1996). On drier sites there seems not to be much difference between growth on hummocks or flat ground (Kangas 2012). Verme and Johnston (1986) suggest that burning after clear cut would be beneficial for NWC regeneration and survival because slower growing post-fire mosses wouldn't suffocate 
the seedlings or dry out like the more common mosses. Soil chemistry is also important with low $\mathrm{pH}$ negatively affecting NWC growth in its younger stages (Nelson 1951, Cornell 2001).

Disturbances that affect the hydrology of NWC swamps can also hinder the recruitment and growth of NWC. Forestry operations like thinning and clear cutting often raise the water table (Heikurainen and Päivänen 1970). Ditches on the other hand, remove water from the wetland and lower water tables (Buchanan et al. 2013). Drainage also affects water chemistry (e.g., $\mathrm{pH}$ and the amount of nutrients) which can in turn lead to changes in species composition (Holden et al 2006, Tahvanainen 2011). Depending on the level of drainage and site conditions, moss species can become more forest moss dominated or more Sphagna dominated (Minkkinen et al. 1999, Tahvanainen 2011). Roads can have many types of adverse effects on swamps. They can alter hydrology by both ponding water on the up gradient side, and lower water table levels on the down gradient side. A high density of roads near a wetland has also been found to lower native plant species richness (Houlahan et al 2006). Plant cover and richness can also be lowered by road salting. Salting can lead to increased salinity up to $300 \mathrm{~m}$ from the road (Richburg et al 2001).

\subsection{Mosses and disturbance - how mosses are affected by disturbance}

Bryophytes have narrow habitat ranges and are sensitive to changes in habitat quality and microclimate (Vitt and Wieder 2009, Kangas et al. 2014). This means that disturbances to moisture or light conditions can lead to changes in their environment and thus affect moss community structure and production (Hylander et al. 2005, Shield et al. 2007, Vitt and Wieder 2009, Schmalholz and Hylander 2011). For instance, Schmalholz and Hylander (2011) found that after clear cuts, bryophytes survived better in protected places such as sheltered by boulders and stumps than in the open. 
Microtopography is also useful in protecting bryophytes from microclimatic stress, such as drier conditions, and mechanical disturbances. Desiccation negatively affects the ability of mosses to photosynthesize. The level of recovery of mosses is dependent on the amount of time they were dry. Most mosses are able to withstand desiccation to some extent, but species of wet or shady habitats are more sensitive to drying out (Busby et al. 1978, Proctor 2009). Many species that are sensitive to drying could therefore disappear from disturbed areas, unless there was sufficient microtopography where they could be protected from the changes in their environment (Schmalholz and Hylander 2010).

However, in these sheltered places bryophyte species with creeping low growth forms (e.g., liverworts) can be negatively affected by litter burial (Schmalholz and Granath 2014). Dense litter can also have a negative effect on bryophyte species density. Hylocomium splendens, Pleurozium schreberi, Dicranum polysetum and Dicranum scoparium have been found to be more abundant in a managed forest with less litter fall than an unmanaged forest (Schmalholz et al. 2011). However, naturally regenerated stands typically have higher species richness than managed stands (RossDavis and Frego 2004, Schmalholz et al. 2011).

Schmalholz et al. (2011) found that disturbance type in boreal forests didn't affect bryophyte richness much, although species composition varied by disturbance type (clear cuts, wild fire and spruce budworm). Also disturbance severity has an effect on moss species composition (Rydgren et al. 2004). Stands disturbed by spruce budworm had species compositions closer to that of mature, undisturbed stands, with more epixylic, wood growing species than the other disturbances. Clear cut stands had the most epigenists, species growing on soil. Different disturbances could lead to shortages of different substrates, leading to this variation in species composition. For example, if a disturbance destroys all CWD, then species that rely on this substrate are negatively affected (Dynesius and Hylander 2007, Schmalholz et al. 2011).

The effects of disturbances can have long term consequences on mosses. The effects of clear cuts on species composition can be seen 30 to 50 years after the 
harvests (Dynesius and Hylander 2007). Other stand replacing disturbance could also have this long effect on mosses. There can be a short increase in species richness after a disturbance when species growing in disturbed habitats have their chance to thrive, but in the case of clear cuts it is only up to three years and after that species richness declines. Cover, on the other hand, increases slowly after disturbance, so that even after several years, it is still not at pre-disturbance levels (Rydgren et al. 20014). In the very short term the reaction of bryophytes to disturbance is a significant loss of richness (Hylander et al. 2005, Dynesius and Hylander 2007). Rydgren et al. (2004) found that after about three years, depending on the severity of the disturbance, the species composition starts to slowly shift towards what it was before disturbance.

\section{Methods}

\subsection{Study sites}

The study was conducted in NWC swamps in northern Minnesota and the Upper Peninsula of Michigan. The study sites are situated in the temperate zone of the western Great Lakes forests ecoregion with a broadleaf and mixed forests main habitat type (Ricketts et al. 1999). The climate is continental with some areas receiving lakeeffect snow. The study sites were selected from a range of NWC swamps. In May and June of 2012, 17 plots from 12 stands were sampled. Eleven plots were from different disturbances and 6 were undisturbed. Drying due to roads was the main disturbance for 5 plots, path with invasive reed canary grass (Phalaris arundinacea) for 1, flooding due to road and construction also for 1 and forestry operations (thinning, clear cut with burning and other forestry operation) for 3 plots. All undisturbed plots were situated in Michigan (Table 3.1). Over all 13 plots were taken in Michigan and 4 in Minnesota. 
Table 3.1: Coordinates, state and disturbance type of the study sites.

\begin{tabular}{lccc}
\hline Site & Condition & State & Coordinates \\
\hline Bob's lake 1 & Thinning in the past & MI & $46^{\circ} 12^{\prime} 36.84^{\prime \prime}-087^{\circ} 30^{\prime} 35.10^{\prime \prime}$ \\
Bob's lake 2 & Undisturbed & MI & $46^{\circ} 12^{\prime} 37.60^{\prime \prime}-087^{\circ} 30^{\prime} 30.20^{\prime \prime}$ \\
Chassell & Undisturbed & MI & $46^{\circ} 57^{\prime} 42.23^{\prime \prime}-88^{\circ} 27^{\prime} 59.91^{\prime \prime}$ \\
Christmas & Road & MI & $46^{\circ} 26^{\prime} 00.18^{\prime \prime}-086^{\circ} 40^{\prime} 57.78^{\prime \prime}$ \\
Dukes & Undisturbed & MI & $46^{\circ} 21^{\prime} 37.81^{\prime \prime}-87^{\circ} 9^{\prime} 23.26^{\prime \prime}$ \\
Eagle Harbor 1 & Canopy disturbance & MI & \\
Eagle Harbor 2 & Between gaps & MI & $47^{\circ} 27^{\prime} 6.97^{\prime \prime}-88^{\circ} 9^{\prime} 17.40^{\prime \prime}$ \\
Eagle Harbor 3 & Undisturbed & MI & \\
Hwy 71 & 2-lane road & MN & $48^{\circ} 01^{\prime} 29.16^{\prime \prime}-094^{\circ} 02^{\prime} 35.94^{\prime \prime}$ \\
Marsin 1 & Path with reed canary grass & MI & $47^{\circ} 10^{\prime} 56^{\prime \prime}-088^{\circ} 38^{\prime} 19^{\prime \prime}$ \\
Marsin 2 & Roadside with ditch & MI & $47^{\circ} 10^{\prime} 58^{\prime \prime}-088^{\circ} 38^{\prime} 09^{\prime \prime}$ \\
Oldman road & Road & MN & $48^{\circ} 04^{\prime} 34.14^{\prime \prime}-094^{\circ} 26^{\prime} 43.02^{\prime \prime}$ \\
Road 1 & Road with big ditches & MN & \\
Seney & Undisturbed & MI & $46^{\circ} 34^{\prime} 13.26^{\prime \prime}-085^{\circ} 34^{\prime} 48.51^{\prime \prime}$ \\
Shingleton 1 & Clear cut and burn & MI & $46^{\circ} 22^{\prime} 36^{\prime \prime}-086^{\circ} 26^{\prime} 31^{\prime \prime}$ \\
Shingleton 2 & Undisturbed & MI & $46^{\circ} 22^{\prime} 41^{\prime \prime}-086^{\circ} 26^{\prime} 26^{\prime \prime}$ \\
Waldo rd & Flooded, road and construction & MN & \\
& nearby & & \\
\hline
\end{tabular}

\subsection{Sampling methods}

The composition of moss species was collected with the relevé sampling method (Mueller-Dombois et al. 1974). In this method, the cover classes of all species present are estimated from a relevé plot with a defined size. A plot size of $25 \mathrm{~m}^{2}$ was chosen instead of the 1-4 $\mathrm{m}^{2}$ minimal area for moss communities given in Mueller-Dombois et al. (1974). This decision was made because the relevé needed to encompass all the main microtopographical features of northern white cedar swamps. In the field it was easy to notice that the smaller plot size would not have been able to capture all the moss species, even if separate plots of different microforms had been taken. When relevé size was enlarged from $25 \mathrm{~m}^{2}$, no new species were found, so the size was considered adequate (Mueller-Dombois et al. 1974).

The relevé was placed in a representative homogenous area that contained all the microtopography of the stand, covering pool, peat surface, trees and coarse woody 
debris (Mueller- Dombois et al, 1974). Several relevés were taken if the site was affected by different disturbances.

All mosses inside the relevé were identified to species level. Mosses that could not be identified on site were collected for later identification in the lab with a microscope and comparisons to the moss collection at MTU. The microform was also recorded where each species was found. Microforms were categorized as either: peat surface, pool, tree base or coarse woody debris (CWD). Surface area per species per substrate was also estimated. It was not recorded as cover percentage but as a cover class ranging from 1 to 6 (Table 3.2).

Several environmental parameters were measured at the relevé scale. Electrical conductivity and $\mathrm{pH}$ of the groundwater were measured with an YSI63 monitor (YSI Incorporated, Yellow Springs, Ohio, USA). Water chemistry was measured in open water, or if open water was not present, a hole was dug and allowed to fill with water.

Table 3.2: Cover classes with corresponding cover percentages.

\begin{tabular}{cll}
\hline Cover class & Cover area, $\%$ & Middle point \\
\hline $\mathbf{6}$ & $75-100$ & 87.5 \\
$\mathbf{5}$ & $50-75$ & 62.5 \\
$\mathbf{4}$ & $25-50$ & 37.5 \\
$\mathbf{3}$ & $5-25$ & 15 \\
$\mathbf{2}$ & $1-5$ & 2.5 \\
$\mathbf{1}$ & $0-1$ & 0.5 \\
\hline
\end{tabular}

Light conditions at the forest floor level were estimated by measuring canopy coverage, as openness, with a spherical densitometer in the middle of the relevé in four directions. The results were averaged and multiplied by 1.04 to get the mean light conditions of the relevé. Peat depth was measured by inserting a tile probe into the peat until it hit the underlying material. The wetness of the site was estimated at each site using a scale of 1 to 3 . One was dry with no signs of open water and 3 was 
wet with abundant pools. Also site description and information on the condition of the site were noted.

\subsection{Data analysis}

Beta diversity was calculated to see how high the compositional diversity between the sites was. The variation between sites is higher the larger the beta diversity is (McCune and Grace 2002). The following equation (Whittaker 1972) was used:

$\beta w=S c \div \bar{S}$

Where:

$\beta_{w}$ is beta diversity

$S_{c}$ is total number of species in the data set

$\bar{S}$ is the average number of species in the sample units.

To check if species richness and cover were affected by disturbance, one-way ANOVAs were done with SPSS Statistics version 21. The plots were divided into two groups: disturbed and undisturbed and then divided by disturbance. Cover and species richness among plots was normally distributed, so transformations were not necessary.

Further analysis of the data was done with PC-ORD version 5.33. Multiple response permutation procedures (MRPP) were run to test if there were differences in community composition between disturbance groups. Sørensen's distance measure was used and four groups were divided by disturbance type. Size of groups ranged from 3 to 6 plots. MRPP tests for differences between predefined groups. It gives a pvalue and a value of chance-corrected within-group agreement (A) that describes the homogeneity within groups, which is between -1 and 1 . The closer to 1 the value is the more identical the sites within the group are. Correspondingly, values close to 0 mean the differences are random. Often in community ecology the value is below 0.1 , even when there are differences (McCune and Grace 2002). 
Hierarchical agglomerative cluster analysis was used to group the moss species data. The analysis was done using Sørensen's distance measure and flexible beta linkage method where $\beta$ was -0.25 (McCune and Grace 2002).

Nonmetric multidimensional scaling (NMS) was used to identify major gradients in community composition. Species that occurred only once were ignored in the NMS analyses to lessen background noise. The midpoints of percent cover of the cover classes were used to represent cover (Table 3.2). Disturbances were categorized as undisturbed, wet roads, dry roads or canopy disturbed. NMS was run on autopilot mode with Sørensen's (Bay-Curtis) distance measure. The starting configuration was set to random. 250 runs were done with both the real data and the randomized data for the Monte Carlo test (McCune and Grace 2002).

Indicator species analysis (Dufrêne and Legendre 1997) was used to identify if there were species that were specifically related to types of disturbances. In this method comparisons are made within-species and the abundances and occurrences of other species don't affect the results unlike in TWINSPAN (Dufrêne and Legendre 1997). Every species is given an indicator value between 0 and 100 based on how well it indicates a certain group. The higher the indicator value is the better is the confidence in it. To be an indicator species, the species has to be found in most of the sites belonging to a certain group and mainly only in that group (Dufrêne and Legendre 1997). The same four groups of disturbance type were used as for MRPP and NMS. There were 4999 randomized runs.

\section{Results}

\subsection{Environmental variables}

The average $\mathrm{pH}$ for the sites was 6.48 , rangeing from 5.29 to 7.48 . Wet roads had the highest average $\mathrm{pH}$ with 6.9 and dry roads the lowest with an average of 6.3 (Table 3). 
In Minnesota $\mathrm{pH}$ was slightly higher $(\mathrm{pH} 6,77)$ than in Michigan where it was 6,40 . Peat depth ranged from $40 \mathrm{~cm}$ to $350 \mathrm{~cm}$, averaging $131 \mathrm{~cm}$. Roads had the lowest peat depth and canopy disturbed sites the highest. Electrical conductivity ranged between 62 and $393.9 \mu \mathrm{S} \mathrm{cm}^{-1}$ and averaged $185.39 \mu \mathrm{S} \mathrm{cm}^{-1}$ across sites. Undisturbed sites had the highest average conductivity with $203.35 \mu \mathrm{S} \mathrm{cm}^{-1}$ and dry roads the lowest, $134.3 \mu \mathrm{S} \mathrm{cm}^{-1}$. Mean canopy openness was $10.8 \%$. Dry roads had the most closed canopies at an openness average of 5.7\%. Wet roads and canopy disturbances (excluding the clear cut) had higher averages at $13.4 \%$ and $17 \%$ respectively. Undisturbed sites had a canopy openness of $10.8 \%$ (Table 4.1 ).

Table 4.1: Environmental variables of the study sites by disturbance type.

\begin{tabular}{lcccccc}
\hline & $\begin{array}{c}\text { Peat } \\
\text { depth, } \\
(\mathbf{c m})\end{array}$ & $\mathbf{p H}$ & $\begin{array}{c}\text { Electrical } \\
\text { conductivity, } \\
\left(\boldsymbol{\mu} \mathbf{S ~ c m}^{-1}\right)\end{array}$ & $\begin{array}{c}\text { Canopy } \\
\text { openness, } \\
\mathbf{\%}\end{array}$ & $\begin{array}{c}\text { Wetness } \\
\text { index }\end{array}$ & $\begin{array}{c}\# \\
\text { Species }\end{array}$ \\
\hline Undisturbed & 138.0 & 6.43 & 203.35 & 10.78 & 2.2 & 13.7 \\
Road, dry & 92.5 & 6.25 & 134.28 & 5.68 & 1.3 & 11.3 \\
Road, wet & 91.0 & 6.88 & 150.97 & 13.43 & 3.0 & 12.0 \\
Canopy & 216.7 & 6.55 & 210.67 & 17.00 & 1.3 & 9.0 \\
\hline
\end{tabular}

\subsection{Species richness and cover}

Sixty-two species of mosses were identified in 33 genera (Appendix 1). An additional 22 samples were taken but could not identified. However, not all samples were unique species. Mniaceae ( 7 species) and Sphagnum (6 species) were the most species rich genera. Species richness varied between 7 and 21 species, averaging 13.2 species across all sites. Beta diversity across sites was 5.83 .

Undisturbed sites had an average of 14.8 species per plot and disturbed sites had 12.3 species per plot (Table 4.2), however, there was no significant difference between them $(\mathrm{p}=0.151)$ (Table 4.3$)$. The test of homogeneity of variance also indicated that variances were equal (Appendix 2, Table 2). Neither were there 
differences between disturbance types $(\mathrm{p}=0.422)$. Wet sites were the most species rich (15.6) and dry sites (11.3) the most species poor, but again not statistically so.

Table 4.2: Species count for plots and divided by disturbance and microforms.

\begin{tabular}{llllllll}
\hline & All plots & Disturbed & Undisturbed & $\begin{array}{l}\text { Peat } \\
\text { surface }\end{array}$ & Pool & $\begin{array}{l}\text { Tree } \\
\text { base }\end{array}$ & CWD \\
\hline $\begin{array}{l}\text { Absolute } \\
\text { count }\end{array}$ & 62 & 54 & 38 & 39 & 7 & 26 & 36 \\
$\begin{array}{l}\text { Average } \\
\text { count/plot }\end{array}$ & 13.2 & 12.3 & 14.8 & 6.4 & 2.3 & 3.7 & 4.8 \\
Max/plot & 21 & 16 & 21 & 13 & 3 & 6 & 9 \\
Min/plot & 7 & 7 & 11 & 3 & 1 & 2 & 1 \\
\hline
\end{tabular}

Table 4.3: ANOVA table of species richness between disturbed and undisturbed plots.

\begin{tabular}{lrrrrr}
\hline & Sum of Squares & df & Mean Square & F & P-value \\
\hline Between Groups & 25.455 & 1 & 25.455 & 2.286 & 0.151 \\
Within Groups & 167.015 & 15 & 11.134 & & \\
Total & 192.471 & 16 & & & \\
\hline
\end{tabular}

Twenty three (37.1\%) of the moss species were found only at one site (Appendix 1). There was no trend to which microform these singular species occurred on, but most of them were found in disturbed sites. Dicranum scoparium was found on all undisturbed plots. Dicranum montanum, Pleurozium schreberi, Rhytidiadelphus triquetrus and Thuidium delicatulum were found on all but one of the undisturbed plots. T. delicatulum also occurred on all disturbed plots. Callicladium haldanianum occurred on all but three of the disturbed plots.

Thuidium delicatulum was overall the most abundant moss; its average cover was 3 and it occurred in all plots but one undisturbed plot. However, on this plot another Thuidium species, Thuidium recognitum, was present. The second most common moss was Dicranum scoparium, which was present on all plots except four disturbed plots. Climacium dendroides had higher average cover classes than $D$. 
scoparium, but occurred on less plots.

The highest absolute cover class was 5 and it was for an undisturbed site. The lowest cover class observed was 2 , both for an undisturbed and disturbed site. The rest of the lowest covers were for disturbed sites in the higher end of cover class 2, two dry road sites and two sites with canopy disturbance. There was no statistical difference in absolute cover between disturbed and undisturbed sites $(\mathrm{P}=0.474)$ (Table 4.4) nor between disturbance types $(p=0.214)$. Cover was highest for sites with canopy openness ranging from 6 to $11 \%$. There was a slight rising trend to cover with increasing wetness.

Table 4.4: ANOVA table of cover classes between undisturbed and disturbed sites.

\begin{tabular}{lrrrrr}
\hline & Sum of Squares & df & Mean Square & F & Sig. \\
\hline Between Groups & 0.382 & 1 & 0.382 & 0.540 & 0.474 \\
Within Groups & 10.600 & 15 & 0.707 & & \\
Total & 10.982 & 16 & & & \\
\hline
\end{tabular}

Of the microforms, the most number of species were found on the peat surface, with an average of 6.4 species per plot. On average CWD had 4.8, tree bases had 3.7 and pools had 2.3 species (Table 4.2). T. delicatulum and $C$. dendroides were the most common species growing on peat surfaces. The main species found on tree bases were Campylium chrysophyllum, D. montanum and Fissidens osmundoides. Callicladium haldanianum and D. scoparium were most commonly on CWD. Mnium affine and Calliergon cordifolium were the most common pool species. Some species occurred on multiple substrates.

Peat surface had the highest moss cover of the microforms. Its average cover class was 4 . Tree bases, CWD and pools had average cover classes of 3. Cover class distribution didn't vary between undisturbed and disturbed plots though in the drier plots pools were usually not present. 


\subsection{Moss community composition}

For the multivariate analyses, all the moss species that only occurred once were removed, leaving 39 species. Cluster analysis of the bryophytes identified two major groupings (Figure 4.1). Moss communities were clustered strongly according to a wetness gradient, with dry sites forming one group and wetter sites formed another group (Figure 4.1).

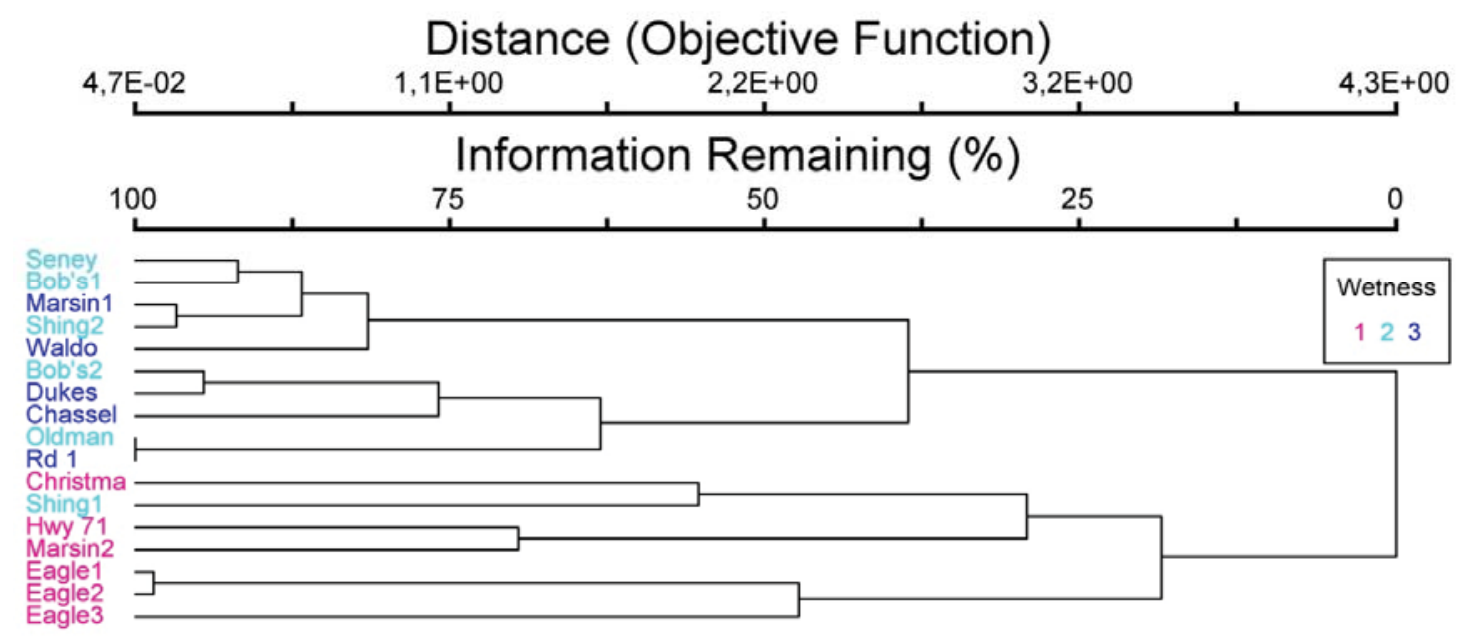

Figure 4.1: Cluster dendrogram of the sites according to wetness.

The final solution for the nonmetric multidimensional scaling (NMS) was reached in 41 iterations. The 2-dimensional solution was the best with a final stress of 15.73569 and a Monte Carlo p-value of 0.0040. After this, reduction of stress was small and adding axes didn't improve conditions (Table 4.5). The stress value was still within acceptable limits (McCune and Grace 2002). The final instability of the solution was 0.00000 
Table 4.5: Stress in relation to dimensionality (number of axes).

\begin{tabular}{cccccccc}
\hline & \multicolumn{2}{c}{ Stress in real data, 250 runs } & \multicolumn{4}{c}{$\begin{array}{c}\text { Stress in randomized data } \\
\text { Monte Carlo test, 250 runs }\end{array}$} \\
\hline Axes & Minimum & Mean & Maximum & Minimum & Mean & Maximum & $\mathrm{p}$ \\
\hline 1 & 29.675 & 45.022 & 54.233 & 32.618 & 47.175 & 54.235 & 0.0040 \\
2 & 15.736 & 18.206 & 35.237 & 16.614 & 22.173 & 36.926 & 0.0040 \\
3 & 11.139 & 11.661 & 24.978 & 9.409 & 13.379 & 25.980 & 0.0797 \\
4 & 7.800 & 8.209 & 19.757 & 6.728 & 8.938 & 20.417 & 0.1514 \\
5 & 5.170 & 5.516 & 6.317 & 4.116 & 6.121 & 13.152 & 0.0876 \\
6 & 3.338 & 3.440 & 11.606 & 2.458 & 4.263 & 6.705 & 0.0438 \\
\hline
\end{tabular}

The NMS explained $68.4 \%$ of the variation in the results. Axis 1 explained most of the variation with an $r^{2}$ of 0.465 . Axis 2 had an $r^{2}$ of 0.219 . Axis 1 correlated most strongly with wetness $\left(r^{2}=0.723\right)$ and somewhat with peat depth $\left(r^{2}=0.022\right)$. Axis 2 correlated with canopy openness $\left(r^{2}=0.196\right)$, and somewhat with $\mathrm{pH}\left(r^{2}=\right.$ 0.027) (Table 4.6).

Table 4.6: Pearson $\left(r^{2}\right)$ and Kendall (tau) correlations with ordination axes, $\mathbf{N}=$ 17.

\begin{tabular}{lcccccr}
\hline \multicolumn{1}{c}{ Axis: } & \multicolumn{1}{c}{$\mathbf{1}$} & & \multicolumn{2}{c}{$\mathbf{2}$} \\
\hline & $\mathrm{r}$ & $\mathrm{r}-\mathrm{sq}$ & tau & $\mathrm{r}$ & $\mathrm{r}$-sq & tau \\
\hline PeatDepth & -.147 & .022 & -.379 & -.110 & .012 & -0.30 \\
pH & .098 & .010 & .170 & -.152 & .023 & -.066 \\
ElecCond & .039 & .002 & -.088 & -.059 & .003 & -.075 \\
CanOp,\% & -.065 & .004 & -.119 & .443 & .196 & .207 \\
Wetness & .851 & .723 & .700 & .085 & .007 & -.070 \\
\hline
\end{tabular}

Like the cluster analysis, the NMS also showed that the moss communities were clearly grouped by wetness of the site (Figure 4.2). Moisture conditions were the main variable controlling community composition. Two distinct communities were formed in the NMS scatter plot based on the groups clustered by wetness (Figure 4.2). 
The drier sites are missing main wetland moss species, like Sphagna, and instead have species more accustomed to dry conditions, like Heterocladium dimorphum and Brotherella recurvans, which were not present in the wetter sites. Some common forest mosses, Hylocomium splendens, Rhytidiadelphus triquetrus and Pleurozium schreberi are also missing from the driest sites.

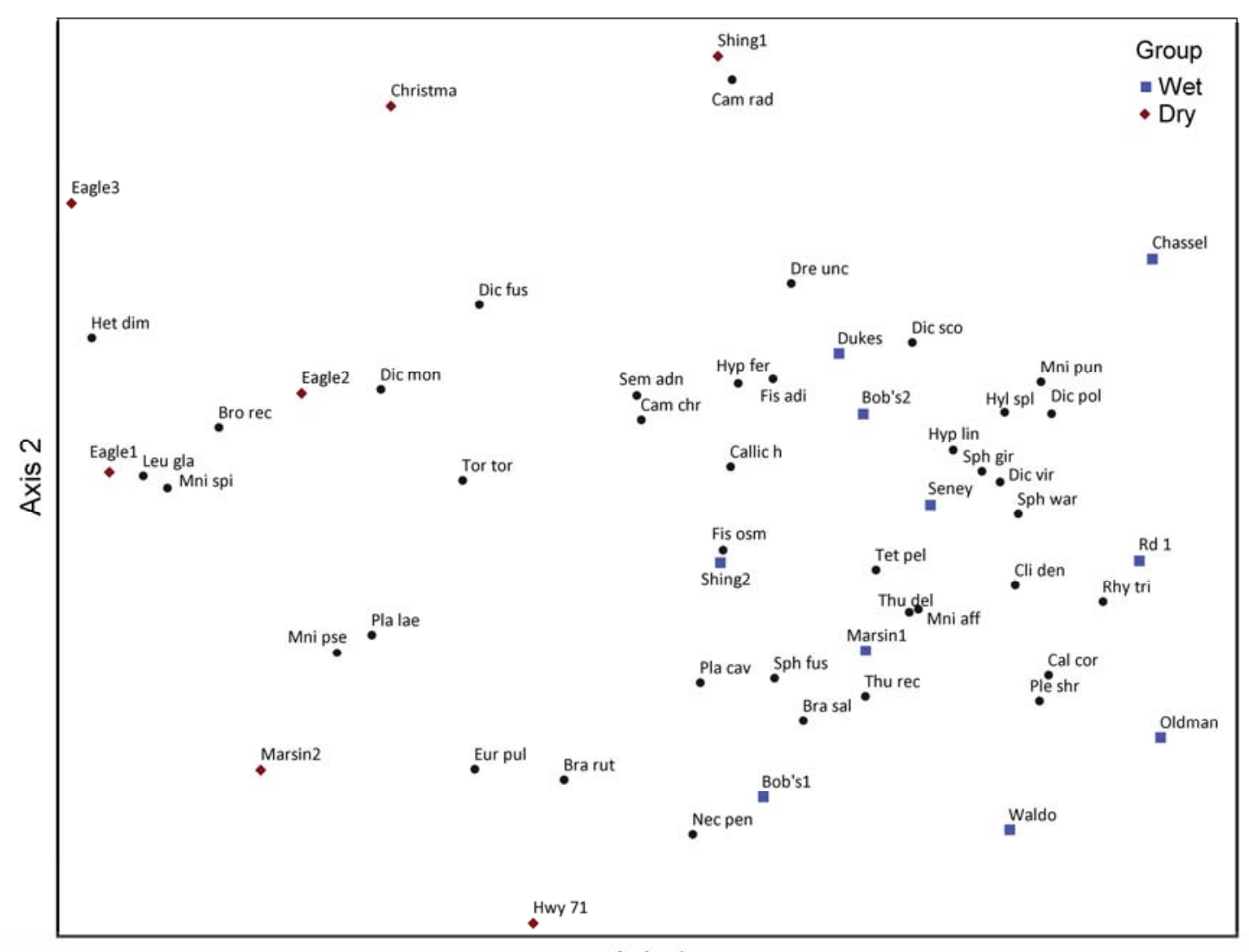

Axis 1

Figure 4.2: 2-dimensional NMS scatter plot showing sites grouped by cluster analysis result. The labels for mosses are composed of the first three letters of their genus and species name.

The first axis in the ordination is related to growing wetness of sites and the undisturbed sites mostly follow the wetness gradient (Figure 4.3) so that they are clustered around the moderately wet to wet parts. However, undisturbed site Eagle3 
(Eagle Harbor 3) is an exception and is situated on the left end of axis 1 .

Axis 1 also divides canopy disturbed and wet road sites to the opposite ends of the wetness gradient. Axis 2 of the ordination is related to disturbance. All the undisturbed sites occure on the upper half of axis 2 and most of the disturbed site occur on the bottom half (Figure 4.3).

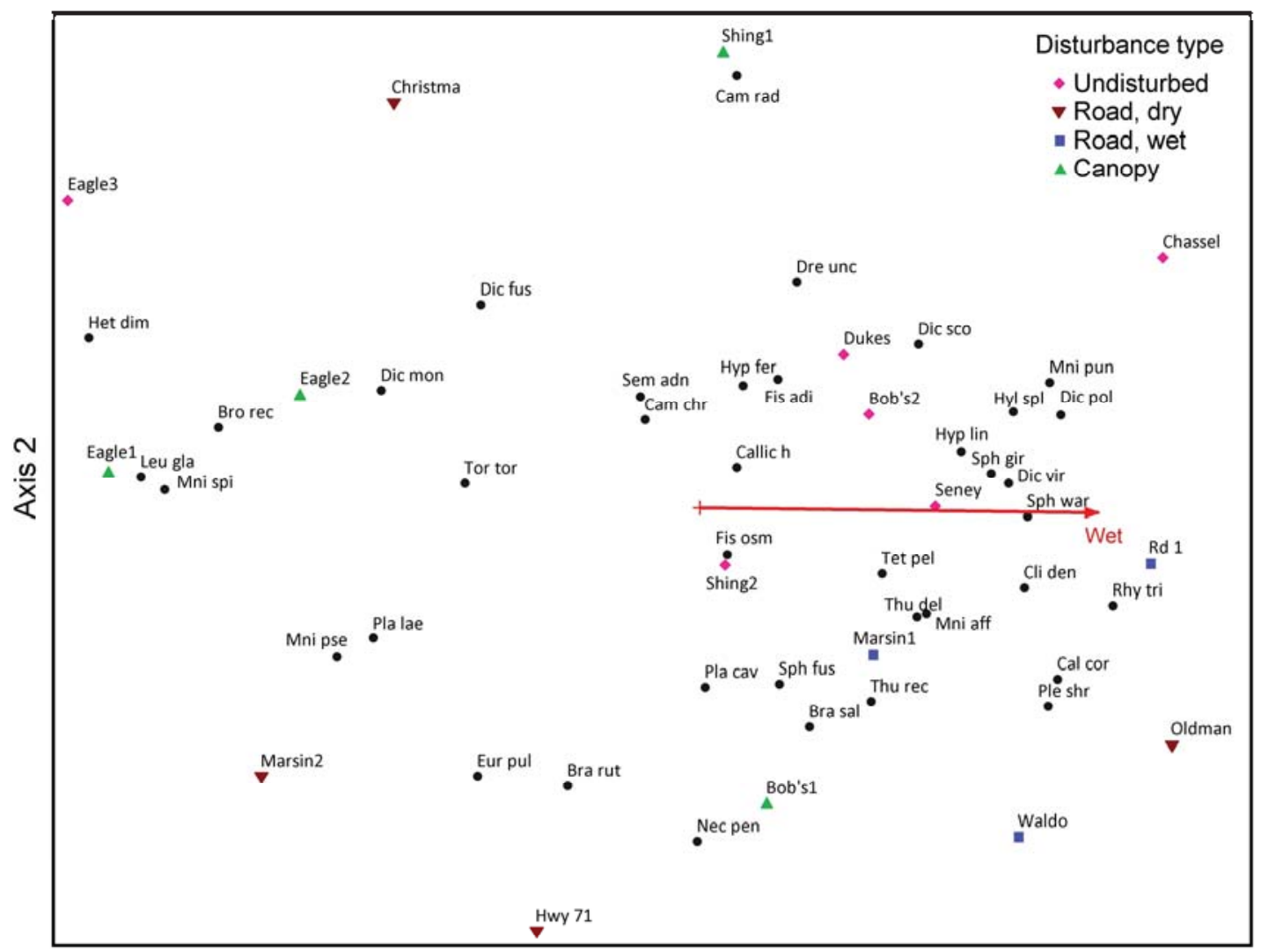

Axis 1

Figure 4.3: 2-dimensional NMS joint-plot showing disturbance types. Wet $=$ wetness of site. 


\subsection{Indicator species}

A Multi-Response Permutation Procedures (MRPP) analysis found that there were significance differences in moss communities between disturbance categories. Chancecorrected within-group agreement, A, was quite small at 0.0598 , but it had a significant p-value of 0.035 . From this it can be concluded that there is some difference between the disturbance types, but that as a whole, the differences were not large (McCune and Grace 2002).

Dicranum fuscescens best indicated undisturbed sites. It had an indicator value (IV) of 50 (Table 4.7). The strongest indicators were for wet roads, sites that were ponded due to roads or paths. These indicators were Calliergon cordifolium, with IV 77.9, and Climacium dendroides with IV 57.8. Eurhynchium pulchellum, on the other hand, indicated sites that had dried due to roads blocking water flow. Its IV was 62.9. The best indicator for sites with some type of canopy disturbance was Brotherella recurvans with an IV of 48.6. However its p-value was 0.1202 .

Table 4.7: Indicator values of best indicator species.

\begin{tabular}{llll}
\hline Species & IV & Group & p-value \\
\hline Dicranum fuscescens & 50 & Undisturbed & 0.0660 \\
Eurhynchium pulchellum & 62.9 & Roads, dry & 0.0662 \\
Calliergon cordifolium & 77.9 & Roads, wet & 0.0082 \\
Climacium dendroides & 57.8 & Roads, wet & 0.0508 \\
Brotherella recurvans & 48.6 & Canopy disturbances & 0.1202 \\
\hline
\end{tabular}




\section{Discussion}

\subsection{Species richness and cover}

In this study there were no statistically significant differences in species richness or cover class between disturbed and undisturbed sites. Other studies have also not found differences in species richness between disturbances like clear cuts, wildfire and spruce budworm, and undisturbed forests (e.g. Schmalholz et al. 2011). Natural and planted forests also have similar species richnesses (Humphrey et al. 2002). Most of the sites with the highest number of species were undisturbed. Shingleton 1 that had been clear cut and burned the previous summer was also amongst the most species rich sites. This is in line with Hylander et al. (2005), who found that diversity rises in the short term after disturbance.

On average, wet sites were the most species rich, although sites that were wet due to hydrological disturbances were not amongst the most species rich. This contrasts with Fitz et al. (2009), who found that bryophyte species richness tends to decrease with increasing hydrologic permanence. Also Vasander (1984) found that wet hollows often have lower species diversity than other microforms but that lowered water tables could hinder moss diversity and growth. In fens, on the other hand, it has been found that increases in water tables lead to higher moss cover (Weltzin et al. 2003).

The driest sites were the least species rich. Dry sites were found to have significantly less moss species than wet sites. This may be due to that fact that many mosses are sensitive to dry conditions because they do not possess roots. Therefore, drying out a site will eliminate those species. In addition, lower moss cover and diversity in dry areas can in part be due to a change in available habitat. The wetter sites had different microforms to grow in than the drier sites as the drier sites did not have pools. They also lacked microtopography in the form of pools that the other sites had. A high heterogeneity of microtopography usually relates to higher bryophyte 
species richness (Vitt et al. 1995, Newmaster et al. 2003, Shields et al. 2007). This would naturally lead dry sites with less microtopography to have less moss species, even though they might be undisturbed. In addition, drying out of a site can lower species richness. For instance, Vasander (1984) found that plant diversity decreased in drained bogs, except in moist hollows, where it increased. Moss cover was also found to be lower in bogs with lowered water tables (Weltzin et al. 2003).

Changing light conditions from canopy disturbances have been found to modify the coverage and richness of mosses. This could be from either too much light, or a decrease in light from shading from other plants that expanded their cover after removing the trees. For example, in disturbed springs competition from vascular plants led to shading and lower moss cover classes (Juutinen and Kotiaho 2009). Hylander et al. (2005) found that average moss cover decreased in buffer strips and clear cuts. Too little light has been often found to lower moss cover (Rambo and Muir 1998??). In this study the lowest cover of mosses was found at the site with the lowest light level. Cover class was also on the lower end for the clear cut site. The greatest moss cover was found in areas with relatively low canopy openness. This is in line with Rambo and Muir (1998) who found that more diffuse light typically increases moss cover. Some studies have also found that a more open canopy leads to decreased species richness (Arseneault et al. 2012). No clear trend like this was found in this study, though the differences in canopy openness were quite small.

\subsection{Moss community composition}

Despite the fact that $\mathrm{pH}$ and electrical conductivity are known to be strong indicators of NWC swamps and peatlands in general (Vitt et al. 1995), they had very low explanatory power in this study. This was probably due to the small variation in $\mathrm{pH}$ and electrical conductivity measured across the study sites. Besides two extremes, from a disturbed and undisturbed site, $\mathrm{pH}$ was quite even across the sites and there was no trend seen for higher or lower $\mathrm{pH}$ between the disturbed and undisturbed sites. All 
the sites in this study had $\mathrm{pH}$ levels that were in the range of values known to be good habitat for NWC.

Here disturbed and undisturbed sites mostly had different moss community compositions. There was also some difference in composition between disturbance types. This agrees with studies that have found that disturbance type and severity affect community composition (e.g. Rydgren et al. 2004 and Schmalholz et al. 2011).

Most of the variation in NWC swamp moss communities was due to site wetness. There is a correlation between undisturbed sites and higher wetness index, which indicates that undisturbed sites are usually not dry. The only exception to this was Eagle Harbor 3, which is characterized by dry and dark conditions. It is possible that Eagle Harbor 3 is actually naturally drier than the other undisturbed sites, or that an unseen disturbance is drying of the site.

Moss community composition was also most strongly correlated with wetness. For instance, many species known to grow in wetter habitats, like Calliergon cordifolium and Mniums were associated with NWC sites that were classified as having wet conditions. Interestingly Dicranum polysetum was also grouped on the wetter end, though it is not a species typically associated with wet habitats. Hylocomium splendens was strongly associated with the wetter undisturbed sites and Pleurozium schreberi with wetter disturbed sites. Most mosses found on wetter sites were epigeic (growing on soil).

H. splendens and P. schreberi were almost completely missing from drier sites, even though they are common in, for example, drained spruce swamps and they are adapted to dry conditions and low light levels (Kangas et al. 2014). Feather mosses are also often associated with drier conditions but they can occur in many types of habitats (Busby et al. 1978, Fenton and Bergeron 2006). In dry sites the majority of species present were epixylic (growing on decaying wood).

Some species were found on both wet and dry sites. Sphagnum fuscum is one example of these. It grows on hummocks, so it can also grow in the wetter sites, especially if the area is a bit more open (Crum and Anderson 1981, Fenton and Bergeron 2006). 
Light can affect species compositions, like aspect affecting the way species respond to disturbances. Åström et al. (2007) found that species compositions changed differently on south and north slopes after clear cut. Feather mosses often require canopy shading to establish (Palviainen et al. 2005, Benscoter and Vitt 2008). Some species, like H. splendens, are able to adapt well to changes in light levels (Busby et al. 1978). However, H. splendens can be sensitive to large changes in light, like those following clear cutting (Palvanainen et al. 2005). P. schreberi, on the other hand, seems to be more restricted by light conditions and needs a more shaded habitat (Fenton and Bergeron 2006, Shields et al. 2007). Here they were not present in stands that were more open due to canopy disturbances.

The presence of Sphagnum girgensohnii and Hylocomium splendens in these NWC swamps is good for the regeneration possibilities of NWC. It has been found that the germination of NWC is better on Sphagnum girgensohnii than on Hylocomium splendens, though long term survival is lower on Sphagnum girgensohnii (St. Hilaire and Leopold 1995). It would seem that germination of NWC is better on mosses with low growth forms (St. Hilaire and Leopold 1995). Sphagnum is also a good substrate for branch layering (Nelson 1951).

\subsection{Indicator species}

Indicator mosses can be used to separate sites according to many variables, like age and heterogeneity of microforms (Newmaster et al. 2003). They have also been used for indicating disturbance types similarly to this study (Juutinen and Kotiaho 2009).

Very few species were found in this study that were suitable indicators. This could be due to the fact that most moss species found were generalists that can grow in numerous types of habitats. Dicranum fuscescens, can be associated with old-growth conditions (Rambo and Muir 1998), was found to be an indicator of undisturbed conditions. It was present on only two of the six undisturbed plots. It could be 
considered an asymmetrical indicator, in that its absence doesn't indicate that the site is disturbed but rather that at least when it is present the site is undisturbed (Dufrêne and Legendre 1997). Calliergon cordifolium, a pool species, had over all the strongest indicator value, indicating wet roads. These sites had a lot of pool area for it to grow in compared to the other sites. Eurhynchium pulchellum, which indicated drier road sites, was found on peat surface, tree bases and CWD, substrates that all benefit from drier conditions. Brotherella recurvans, though it had an IV near 50, should be thought of as weak indicators due to its high p-value.

This short list of indicator species should be useful in quickly assessing conditions in NWC swamps. However, Frego (2007) suggests that teaching people to identify indicator species could be a problem, depending on the number and characteristics of the species to be identified. The indicator species found in this study can be identified easily in the field, without the need for a microscope, and with as small a list of indicators as this study produced, this shouldn't be an issue. The accuracy of the indicators still needs to be tested further in the field.

\subsection{Limitations of the work}

The sample size of this study was relatively small due to travel and time constraints. Additional sampling of more sites could increase the reliability of the results. Also the scope of the disturbances sampled was not wide. The sites sampled were not chosen wholly randomly, so using ANOVA might not give the most reliable results. Converting cover classes into percentages for the analyses could have led to under- or overestimation of cover for some moss species. However, it is expected that this possible estimation error is minimal. 


\section{Conclusions}

The disturbances studied in this thesis had no significant effect on moss cover and total species richness in NWC swamps. However, species composition was affected by disturbance and by the wetness of the site. Some indicator species were found, but their level of indication is best for simply indicating disturbed or undisturbed conditions, not for indicating disturbance type besides ponded conditions. Therefore mosses could be used to tell apart undisturbed and disturbed swamps. Field trials should be done to check if the list of mosses works for indicating disturbed and undisturbed conditions.

This study could be expanded by studying mosses on restored sites to see if their species compositions are similar to undisturbed sites. It would be interesting to know if mosses could be used to indicate levels of success in NWC swamp restoration. Additionally research could concentrate on other disturbances not studied here to find other indicators. 


\section{References}

Aldous, S. E. 1941. Deer management suggestions for northern white cedar types. Journal of Wildlife Management 5(1): 90-94.

Bates, J. W. 2009. Mineral nutrition and substratum ecology. In: Goffinet, B. and Shaw, A. J. (eds.), Bryophyte biology (2nd ed.). Cambridge Univ. Press, p. 299356.

Boucher, Y., Arseneault, D. and Sirois, L. 2006. Logging-induced change (1930-2002) of a preindustrial landscape at the northern range limit of northern hardwoods, eastern Canada. Canadian Journal of Forest Research 36 (2): 505-517.

Boulfroy, E., Forget, E., Hofmeyer, P. V., Kenefic L. S., Larouche, C., Lessard G., Lussier, J.-M., Pinto, F., Ruel, J.-C., and Weiskittel, A. 2012. Silvicultural guide for

northern white-cedar (eastern white cedar). Gen. Tech. Rep. NRS-98. Newtown Square, PA: US. Department of Agriculture, Forest Service, Northern Research Station. $74 \mathrm{p}$.

Buchanan, B., Easton, Z. M., Schneider, R. L. and Walter, M. T. 2013. Modeling the hydrologic effects of roadside ditch networks on receiving waters. Journal of Hydrology 486: 293-305.

Busby, J. R., Bliss, L. C. \& Hamilton, C. D. 1978. Microclimate Control of Growth Rates and Habitats of the Boreal Forest Mosses, Tomenthypnum nitens and Hylocomium splendens. Ecological Monographs. 48 (2): 95-110.

Chimner, R. A and Hart, J. B. 1996. Hydrology and microtopography effects on northern white-cedar regeneration in Michigan's Upper Peninsula. Canadian Journal of Forest Research 26 (3): 389-393.

Cornett, M. W., Puettmann, K. J., Frelich, L. E. \& Reich, P. B. 2001. Comparing the importance of seedbed and canopy type in the restoration of upland Thuja occidentalis forests of northeastern Minnesota. Restoration Ecology 9 (4): 386396. 
Crum, H. A. and Anderson, L. E. 1981. Mosses of eastern North America. Columbia University Press, NY. 1328 p.

Curtis, J. D. 1946. Preliminary observations on northern white cedar in Maine. Ecology 27(1): 23-36.

Dufrêne, M. and Legendre, P. 1997. Species assemblages and indicator species: The need for a flexible asymmetrical approach. Ecological Monographs 67(3): 345366.

Dynesius, M. and Hylander, K. 2007. Resilience of bryophyte communities to clearcutting of boreal stream-side forests. Biological Conservation 135 (3): 423-434.

Fenton, N. J. and Bergeron, Y. 2006. Facilitative succession in a boreal bryophyte community driven by changes in available moisture and light. Journal of Vegetation Science 17: 65-76.

Fitz, K. M., Glime, J. M., Hribljan, J., and Greenwood, J. L. 2009. Can bryophytes be used to characterize hydrologic permanence in forested headwater streams? Ecological Indicators 9(4): 681-692.

Frego. 2007. Bryophytes as potential indicators of forest integrity. Forest Ecology and Management 242 (1): 65-75

The feasibility of northern white cedar wetland creation or restoration as compensatory mitigation for transportation projects in Michigan. Northern ecological services, Inc. 2000 .

Glime, J. M and Hong, W. S. 2002. Bole epiphytes on three conifer species from Queen Charlotte Islands, Canada. The Bryologist 105(3): 451-464.

Heikurainen, L. and Päivänen, J. 1970. The effect of thinning, clear cutting and fertilization on the hydrology of peatland drained for forestry. Acta Forestalia Fennica, 104: 1-23.

Heitzman, E., Pregitzer, K. S. and Miller, R. O. 1997. Origin and early development of northern white-cedar stands in northern Michigan. Canadian Journal of Forest Research 27: 1953-1961.

Heitzman, E., Pregitzer, K. S., Miller, R. O., Lanasa, M. and Zuidema, M. 1999. Establishment and development of northern white-cedar following strip clearcutting. Forest Ecology and Management 123 (2-3): 97-104. 
Hofmeyer, P. V., Kenefic, L. S. and Seymour, R. S. 2009. Northern white-cedar ecology and silviculture in the northeastern United States and southeastern Canada: A synthesis of knowledge. Northern Journal of Applied Forestry. 26(1): 21-27.

Holcombe, J.W. 1976. The bryophyte flora of Thuja seedbed logs in a northern white cedar swamp. Michigan botanist 3: 173.

Holden, J., Evans, M. G., Burt, T. P., and Horton, M. 2006. Impact of land drainage on peatland hydrology. Journal of Environmental Quality 35(5): 1764-1778.

Houlahan J. E., Keddy, P. A., Makkay, K., and Findlay, C. S. 2006. The effects of adjacent land use on wetland species richness and community composition. Wetlands 26(1): 79-96.

Humphrey, J. W., Davey, S., Peace, A. J., Ferris, R. and Harding, K. 2002. Lichens and bryophyte communities of planted and semi-natural forests in Britain: the influence of site type, stand structure and deadwood. Biological Conservation 107(2): 165-180.

Hylander, K., Dynesius, M., Jonsson, B. G. and Nilsson, C. 2005. Substrate form determines the fate of bryophytes in riparian buffer strips. Ecological Applications, 15(2): 674-688.

Johnston, W. F. 1990. Northern White Cedar. In: Burns, R. M and Honkala, B. H. (ed.). Silvics of North America. Vol. 1: Conifers. Agriculture Handbook 654, USDA, Forest Service, Washington DC, p. 580-589.

Juutinen, R., \& Kotiaho, J. S. 2009. Lähteikköjen luonnontilan ja sammallajiston pitkäaikaismuutokset. Suomen ympäristö 19/2009. Suomen ympäristökeskus, Helsinki. 118 p.

Kangas, L. C. 2012. Restoration of forested wetlands: Case studies in Michigan and Finland. Master's thesis, Michigan Technological University, Michigan, USA.

Kangas L.C., Maanavilja, L., Hájek, T., Juurola, E., Chimner, R. R., Mehtätalo L. and Tuittila, E. 2014. Photosynthetic traits of Sphagnum and feather moss species in undrained, drained and rewetted boreal spruce swamp forests. Ecology and Evolution 4: 381-396.

Kost, M. A., Albert, D. A, Cohen, J. G., Slaughter, B. S., Schillo, R. K., Weber, C. R., and Chapman, K. A. 2007. Natural communities of Michigan: classification and 
description. Report 2007-21. Michigan Natural Features Inventory, Lansing, MI. Pp: 3-14, 121-125.

Landres, P. B., Verner, J. \& Thomas, J. W. 1988. Ecological uses of vertebrate indicator species: A critique. Conservation Biology 2(4): 316-328.

Larouche, C., Kenefic, L. S. and Ruel, J-C. 2010. Northern white-cedar regeneration dynamics on the Penobscot Experimental Forest in Maine: 40-Year Results. Northern Journal of Applied Forestry 27 (1): 5-12.

Minkkinen, K., Vasander, H., Jauhiainen, S., Karsisto, M., and Laine, J. 1999. Postdrainage changes in vegetation composition and carbon balance in Lakkasuo mire, Central Finland. Plant and Soil, 207(1): 107-120.

McCune and Grace. 2002. Analysis of ecological communities. Gleneden Beach, Oregon: MjM software design. 300 p.

Mueller- Dombois, D. and Ellenberg, H. 1974. Aims and methods of vegetation ecology. Wiley and Sons, Inc, NY, USA. 547 p.

Mälson, K. \& Rydin, H. 2007. The regeneration capabilities of bryophytes for rich fen restoration. Biological Conservation. 135 (3): 435-442.

Nelson, T. C. 1951. A reproduction study of NWC. Game Division, Michigan Dept. of Conservation, Lansing, MI. 100 p.

Newmaster, S. G., Belland, R. J., Arsenault, A., Vitt, D. H. 2003. Patterns of bryophyte diversity in humid coastal and inland cedar-hemlock forests of British Columbia. Environmental Reviews, suppl. Old-Growth Forests in Canada 11: 159-185.

Pregitzer, K. S., 1990. The ecology of northern white cedar. In: Lantagne, D.O. (Ed.), Northern white-cedar in Michigan, Workshop Proceedings, Feb 21-22, Sault St. Marie, MI. Agricultural Experiment Station Research Report 512: 7-12.

Proctor, M. C. F. 2009. Physiological ecology. In: Goffinet, B. and Shaw, A. J. (eds), Bryophyte biology (2nd ed.). Cambridge Univ. Press. Pp: 237-268

Rambo, T. R and Muir, P. S. 1998. Forest floor bryophytes of Pseudotsuga menziesiiTsuga heterophylla stands in Oregon: Influences of substrate and overstory. The Bryologist 101 (1): 116-130. 
Richburg, J. A., Patterson, W. A., and Lowenstein, F. 2001. Effects of road salt and Phragmites australis invasion on the vegetation of a western Massachusetts calcareous lake-basin fen. Wetlands 21(2): 247-255.

Ricketts, T. H., Dinerstein E., Olson, D. M., Loucks, C. J., Eichbaum, W., DellaSala, D., Kavanagh, K., Hedao, P., Hurley, P. T., Carney, K. M., Abell R and Walters S. 1999. Terrestrial ecoregions of North America: A conservation assessment. Island Press, Washington D.C. 487 p.

Rooney, T. P., Solheim, S. L., Waller, D. M. 2002. Factors affecting the regeneration of northern white cedar in lowland forests of the Upper Great Lakes region, USA. Forest Ecology and Management 163: 119-130.

Rooney, T. P. and Waller, D. M. 2003. Direct and indirect effects of white-tailed deer in forest ecosystems. Forest Ecology and Management. 181(1-2): 165-176.

Ross-Davis, A. L. \& Frego, K. A. 2004. Propagule Sources of Forest Floor Bryophytes: Spatiotemporal Compositional Patterns. The Bryologist. 107 (1): 8897.

Rydgren, K., Økland, R. H. and Hestmark, G. 2004. Disturbance severity and community resilience in a boreal forest. Ecology 85(7): 1906-1915.

Schmalholz, M. and Granath, G. 2014. Effects of microhabitat and growth form on bryophyte mortality associated with leaf litter burial in a boreal spruce forest. Journal of Vegetation Science 25(2): 439-446.

Schmalholz, M and Hylander, K. 2010. Microtopographic influence on recolonization patterns of forest floor bryophytes following clear-cut logging. In: Resistance and recolonization of bryophyte assemblages following disturbances: - detecting patterns and exploring mechanisms. Doctoral thesis, Department of Botany, Stockholm University.

Schmalholz, M. and Hylander, K. 2011. Microtopography creates small-scale refugia for boreal forest floor bryophytes during clear-cut logging. Ecography. 34 (4): 637-648.

Schmalholz, M., Hylander, K. and Frego, K. 2011. Bryophyte species richness and composition in young forests regenerated after clear-cut logging versus after wildfire and spruce budworm outbreak. Biodiversity and Conservation 2011: 20(12): 2575-2596. 
Shields, J. M., Webster, C. R. amd Glime, J. M. 2007. Bryophyte community response to silvicultural opening size in a managed northern hardwood forest. Forest Ecology and Management 252(1-3): 222-229.

St. Hilaire, L.R. and Leopold 1995. Conifer seedling distribution in relation to microsite conditions in a central New-York forested minerotrophic peatland. Canadian Journal of Forest Research 25 (2): 261-269

Sunila, E. S. and Kuttan, G. 2005. Protective effect of Thuja occidentalis against radiation-induced toxicity in mice. Integrative Cancer Therapies 4: 322-328.

Tahvanainen, T. 2011. Abrupt ombrotrophication of a boreal aapa mire triggered by hydrological disturbance in the catchment. Journal of Ecology 99 (2): 404-415.

Vasander, H. 1984. Effect of forest amelioration on diversity in an ombrotrophic bog. Annales Botanici Fennici 21 (1): 7-15.

Verme, L. J. and Johnston, W. F. 1986. Regeneration of northern white cedar deeryards in Upper Michigan. The Journal of Wildlife Management. 50 (2): 307313.

Vitt, D. H., Li, Y. and Belland, R. J. 1995. Patterns of bryophyte diversity in peatlands of continental western Canada. The Bryologist 98(2): 218-227.

Vitt, D. and Wieder R. 2009. Structure and function of bryophyte-dominated peatlands. In: Goffinet, B. and Shaw, A. J. (eds), Bryophyte biology (2nd ed.). Cambridge Univ. Press, p. 357-392.

Weltzin, J. F., Bridgham, S. D., Pastor, J., Chen, J., \& Harth, C. 2003. Potential effects of warming and drying on peatland plant community composition. Global Change Biology 9(2): 141-151.

Whittaker, R. H. 1972. Evolution and measurement of species diversity. Taxon: 213251.

Zasada, Z. 1952. Reproduction on cut-over swamplands in the Upper Peninsula of Michigan. Division of Forest Management, Lake States Forest Experiment Station, US Department of Agriculture--Forest Service.

Zenner, E.K. \& Almendinger, J.C. 2012. Identifying restoration opportunities for northern white cedar by contrasting historical and modern inventories in an ecological classification system context. Ecological Restoration. 30 (3): 169-179. 
Åström, M., Dynesius, M., Hylander, K., Nilsson, C. 2007. Slope aspect modifies community responses to clear-cutting in boreal forests. Ecology 88(3): 749-758. 


\section{APPENDIX 1}

Species list with their cover, main growth locations and frequency.

\begin{tabular}{|c|c|c|c|}
\hline Species & $\begin{array}{c}\text { Average } \\
\text { cover class }\end{array}$ & $\begin{array}{l}\text { Main growth } \\
\text { location }\end{array}$ & Frequency \\
\hline Brachythechium reflexum & 3 & Peat/CWD & 1 \\
\hline B. rutabulum & 2 & Peat/CWD & 2 \\
\hline B. salebrosum & 2 & CWD & 3 \\
\hline Brotherella recurvans & 3 & CWD & 4 \\
\hline Bryum pseudotriquetrum & 2 & CWD & 1 \\
\hline Bryum weigelii & 2 & Pool & 1 \\
\hline Callicladium haldanianum & 2 & CWD/Peat & 11 \\
\hline Calliergon cordifolium & 2 & Pool & 5 \\
\hline Calliergon giganteum & 1 & Pool & 1 \\
\hline Calliergon richardsonii & 4 & Pool & 1 \\
\hline Calliergon stramineum & 1 & Peat & 1 \\
\hline Campylium chrysophyllum & 2 & Tree & 9 \\
\hline Campylium radicale & 2 & CWD/Peat & 2 \\
\hline Cirriphyllum piliferum & 2 & CWD/tree/peat & 1 \\
\hline Climacium dendroides & 2 & Peat/CWD & 8 \\
\hline Dicranum fuscescens & 2 & Peat & 3 \\
\hline D. montanum & 2 & Tree/CWD & 10 \\
\hline D. polysetum & 2 & Peat & 3 \\
\hline D. scoparium & 2 & Peat/CWD & 13 \\
\hline D. viride & 2 & CWD & 3 \\
\hline Drepanocladus aduncus & 3 & Pool & 1 \\
\hline Drepanocladus uncinatus & 2 & CWD & 7 \\
\hline Eurhynchium pulchellum & 3 & Peat/tree/CWD & 7 \\
\hline Fissidens adianthoides & 3 & Tree/CWD & 3 \\
\hline Fissidens osmundoides & 2 & Tree & 9 \\
\hline Funaria flavicans & 1 & Peat & 1 \\
\hline Heterocladium dimorphum & 2 & Tree/CWD & 2 \\
\hline Homalia trichomanoides & 2 & Tree & 1 \\
\hline Hylocomium splendens & 3 & Peat/CWD & 6 \\
\hline Hypnum fertile & 2 & Tree/CWD & 5 \\
\hline Hypnum lindbergii & 2 & Peat/CWD & 5 \\
\hline Leptobryum pyriforme & 1 & Peat & 1 \\
\hline
\end{tabular}




\begin{tabular}{llll}
\hline Leucobryum glaucum & 3 & Peat/CWD & 2 \\
\hline Mnium cuspidatum & 2 & Peat/tree/CWD & 1 \\
\hline M. marginatum & 5 & Tree & 1 \\
M. pseudopunctatum & 2 & CWD & 2 \\
\hline M. puncatatum & 3 & Pool & 2 \\
\hline M. spinulosum & 2 & CWD/tree & 2 \\
\hline M. affine & 3 & Pool & 6 \\
\hline M. affine var. ciliare & 2 & CWD & 1 \\
Neckera pennata & 3 & Tree & 3 \\
\hline Oncophorus wahlenbergii & 3 & CWD & 1 \\
\hline Orthotrichum sordidum & 1 & CWD & 1 \\
\hline Orthotrichum pylaisii & 2 & CWD & 1 \\
\hline Plagiothechium cavifolium & 2 & Peat/tree/CWD & 2 \\
\hline Plagiothechium laetum & 2 & Peat & 4 \\
Pleurozium schreberi & 2 & Peat & 9 \\
\hline Pleurozium splendens & 4 & Peat & 1 \\
\hline Ptilium crista-castrensis & 2 & Peat & 1 \\
\hline Rhytidiadelphus squarrosus & 2 & Peat & 1 \\
\hline Rhytidiadelphus triquetrus & 3 & Peat & 8 \\
\hline Sematophyllum adnatum & 2 & CWD & 3 \\
\hline Sphagnum capillifolium & 1 & Peat & 1 \\
\hline S. centrale & 2 & Peat & 1 \\
\hline S. fuscum & 1 & Peat & 3 \\
\hline S. girgensohnii & 3 & Peat & 3 \\
\hline S. subnitens & 5 & Pool & 1 \\
\hline S. warnstorfii & 2 & Peat & 5 \\
\hline Tetraphis pellucida & 2 & CWD & 6 \\
\hline Thuidium delicatulum & 3 & Peat/tree & 16 \\
Thuidium recognitum & 2 & Peat & 2 \\
Tortella tortuosa & Tree/CWD & \\
\hline & & & 2 \\
\hline
\end{tabular}




\section{APPENDIX 2}

Table 1: Descriptives from ANOVA of species richness in disturbed and undisturbed conditions.

\begin{tabular}{|c|c|c|c|c|c|c|c|c|}
\hline & \multirow[b]{2}{*}{$\mathbf{N}$} & \multirow[b]{2}{*}{ Mean } & \multirow[b]{2}{*}{$\begin{array}{c}\text { Std. } \\
\text { Deviation }\end{array}$} & \multirow[b]{2}{*}{$\begin{array}{l}\text { Std. } \\
\text { Error }\end{array}$} & \multicolumn{2}{|c|}{$\begin{array}{l}\text { 95\% Confidence } \\
\text { Interval for Mean }\end{array}$} & \multirow[b]{2}{*}{ Minimum } & \multirow[b]{2}{*}{ Maximum } \\
\hline & & & & & $\begin{array}{l}\text { Lower } \\
\text { Bound }\end{array}$ & $\begin{array}{l}\text { Upper } \\
\text { Bound }\end{array}$ & & \\
\hline Undisturbed & 6 & 14.833 & 3.9200 & 1.6003 & 10.720 & 18.947 & 11.0 & 21.0 \\
\hline Disturbed & 11 & 12.273 & 3.0030 & .9054 & 10.255 & 14.290 & 7.0 & 16.0 \\
\hline Total & 17 & 13.176 & 3.4683 & .8412 & 11.393 & 14.960 & 7.0 & 21.0 \\
\hline
\end{tabular}

Table 2: Test of homogeneity of variance in species richness between undisturbed and disturbed plots.

\begin{tabular}{cccc}
\hline $\begin{array}{c}\text { Levene } \\
\text { Statistic }\end{array}$ & df1 & df2 & Sig. \\
\hline .701 & 1 & 15 & .415 \\
\hline
\end{tabular}

Table 3: Descriptives from ANOVA of cover class in disturbed and undisturbed conditions.

\begin{tabular}{|c|c|c|c|c|c|c|c|c|}
\hline & \multirow[b]{2}{*}{$\mathbf{N}$} & \multirow[b]{2}{*}{ Mean } & \multirow[b]{2}{*}{$\begin{array}{c}\text { Std. } \\
\text { Deviation }\end{array}$} & \multirow[b]{2}{*}{$\begin{array}{c}\text { Std. } \\
\text { Error }\end{array}$} & \multicolumn{2}{|c|}{$\begin{array}{l}\text { 95\% Confidence } \\
\text { Interval for Mean }\end{array}$} & \multirow[b]{2}{*}{ Minimum } & \multirow[b]{2}{*}{ Maximum } \\
\hline & & & & & $\begin{array}{l}\text { Lower } \\
\text { Bound }\end{array}$ & $\begin{array}{l}\text { Upper } \\
\text { Bound }\end{array}$ & & \\
\hline Undisturbed & 6 & 3.4500 & .98133 & .40062 & 2.4202 & 4.4798 & 2.00 & 4.90 \\
\hline Disturbed & 11 & 3.1364 & .76062 & .22934 & 2.6254 & 3.6474 & 2.00 & 4.50 \\
\hline Total & 17 & 3.2471 & .82849 & .20094 & 2.8211 & 3.6730 & 2.00 & 4.90 \\
\hline
\end{tabular}


Table 4: Test of homogeneity of variance between cover classes of disturbed and undisturbed sites.

\begin{tabular}{rccc}
\hline $\begin{array}{c}\text { Levene } \\
\text { Statistic }\end{array}$ & df1 & df2 & Sig. \\
\hline .067 & 1 & 15 & .799 \\
\hline
\end{tabular}

Table 5: ANOVA of species richness between different disturbance types.

\begin{tabular}{lrrrrr}
\hline & \multicolumn{1}{c}{$\begin{array}{c}\text { Sum of } \\
\text { Squares }\end{array}$} & df & Mean Square & F & \multicolumn{1}{c}{ Sig. } \\
\hline Between Groups & 36.221 & 3 & 12.074 & 1.005 & .422 \\
Within Groups & 156.250 & 13 & 12.019 & & \\
Total & 192.471 & 16 & & & \\
\hline
\end{tabular}

Table 6: Descriptives from ANOVA of species richness between different disturbance types.

\begin{tabular}{|c|c|c|c|c|c|c|c|c|}
\hline & \multirow[b]{2}{*}{$\mathbf{N}$} & \multirow[b]{2}{*}{ Mean } & \multirow[b]{2}{*}{$\begin{array}{l}\text { Std. } \\
\text { Dev. }\end{array}$} & \multirow[b]{2}{*}{$\begin{array}{c}\text { Std. } \\
\text { Error }\end{array}$} & \multicolumn{2}{|c|}{$\begin{array}{c}\text { 95\% Confidence } \\
\text { Interval for } \\
\text { Mean }\end{array}$} & \multirow[b]{2}{*}{ Minimum } & \multirow[b]{2}{*}{ Maximum } \\
\hline & & & & & $\begin{array}{l}\text { Lower } \\
\text { Bound }\end{array}$ & $\begin{array}{l}\text { Upper } \\
\text { Bound }\end{array}$ & & \\
\hline Undisturbed & 6 & 14.833 & 3.9200 & 1.6003 & 10.720 & 18.947 & 11.0 & 21.0 \\
\hline Road, dry & 4 & 12.750 & 2.2174 & 1.1087 & 9.222 & 16.278 & 10.0 & 15.0 \\
\hline Road, wet & 3 & 13.333 & 3.0551 & 1.7638 & 5.744 & 20.922 & 10.0 & 16.0 \\
\hline Canopy & 4 & 11.000 & 3.9158 & 1.9579 & 4.769 & 17.231 & 7.0 & 16.0 \\
\hline Total & 17 & 13.176 & 3.4683 & .8412 & 11.393 & 14.960 & 7.0 & 21.0 \\
\hline
\end{tabular}

Table 7: ANOVA of cover class between different disturbance types.

\begin{tabular}{lrrrrr}
\hline & $\begin{array}{r}\text { Sum of } \\
\text { Squares }\end{array}$ & df & $\begin{array}{r}\text { Mean } \\
\text { Square }\end{array}$ & F & Sig. \\
\hline Between Groups & 3.110 & 3 & 1.037 & 1.712 & .214 \\
Within Groups & 7.873 & 13 & .606 & & \\
Total & 10.982 & 16 & & & \\
\hline
\end{tabular}


Table 8: Descriptives from ANOVA of cover class between different disturbance types

\begin{tabular}{|c|c|c|c|c|c|c|c|c|}
\hline & \multirow[b]{2}{*}{$\mathbf{N}$} & \multirow[b]{2}{*}{ Mean } & \multicolumn{4}{|c|}{$\begin{array}{l}\text { 95\% Confidence } \\
\text { Interval for Mean }\end{array}$} & \multirow[b]{2}{*}{ Minimum } & \multirow[b]{2}{*}{ Maximum } \\
\hline & & & $\begin{array}{l}\text { Std. } \\
\text { Dev. }\end{array}$ & $\begin{array}{l}\text { Std. } \\
\text { Error }\end{array}$ & $\begin{array}{l}\text { Lower } \\
\text { Bound }\end{array}$ & $\begin{array}{l}\text { Upper } \\
\text { Bound }\end{array}$ & & \\
\hline Undisturbed & 6 & 3.45 & .981 & .401 & 2.42 & 4.48 & 2 & 5 \\
\hline Road, dry & 4 & 3.22 & .922 & .461 & 1.76 & 4.69 & 3 & 5 \\
\hline Road, wet & 3 & 3.80 & .100 & .058 & 3.55 & 4.05 & 4 & 4 \\
\hline Canopy & 4 & 2.55 & .404 & .202 & 1.91 & 3.19 & 2 & 3 \\
\hline Total & 17 & 3.25 & .828 & .201 & 2.82 & 3.67 & 2 & 5 \\
\hline
\end{tabular}

